\title{
An experimental model of the epithelial to mesenchymal transition and pro-fibrogenesis in urothelial cells related to bladder pain syndrome/interstitial cystitis
}

\author{
Xing-Wei Jin, Qi-Zhang Wang, Yang Zhao, Bo-Ke Liu, Xiang Zhang, Xian-Jin Wang, Guo-Liang Lu, \\ Jun-Wei Pan*, Yuan Shao* \\ Department of Urology, Ruijin Hospital, Shanghai Jiao Tong University School of Medicine, Shanghai, China \\ Contributions: (I) Conception and design: XW Jin, JW Pan, Y Shao; (II) Administrative support: None; (III) Provision of study materials or patients: \\ XW Jin, Y Zhao, X Zhang; (IV) Collection and assembly of data: QZ Wang, JW Pan, GL Lu; (V) Data analysis and interpretation: XW Jin, BK Liu, \\ XJ Wang, JW Pan, Y Shao; (VI) Manuscript writing: All authors; (VII) Final approval of manuscript: All authors. \\ *These authors contributed equally as co-correspondences. \\ Correspondence to: Yuan Shao; Jun-Wei Pan. Department of Urology, Ruijin Hospital, Shanghai Jiao Tong University School of Medicine, No. 197 \\ Ruijin Er Road, Shanghai 200025, China. Email: shaoyuan15@hotmail.com; pjw_tenor@outlook.com.
}

Background: Suitable in vitro models are needed to investigate urothelial epithelial to mesenchymal transition (EMT) and pro-fibrogenesis phenotype in bladder pain syndrome/interstitial cystitis (BPS/IC). This study is to establish a novel experimental BPS/IC cell model and explore how different concentrations of tumor necrosis factor (TNF)- $\alpha$ influence the EMT and pro-fibrogenesis phenotype of urothelial cells.

Methods: SV-HUC-1 urothelial cells were cultured with 2, 10, or $50 \mathrm{ng} / \mathrm{mL}$ TNF- $\alpha$ to mimic chronic inflammatory stimulation. The EMT and pro-fibrogenesis phenotype, including production of collagen I and pro-fibrosis cytokines, were estimated after $72 \mathrm{~h}$ of culture.

Results: The bladder urothelial cells of BPS/IC exhibited upregulated vimentin, TNF- $\alpha$ and TNF receptor, downregulated E-cadherin, and increased collagen I. Higher concentrations of TNF- $\alpha$ (10 and $50 \mathrm{ng} / \mathrm{mL}$ ) produced an obvious mesenchymal morphology, enhanced invasion and migratory capacity, increased expression of vimentin, and decreased expression of E-cadherin. Collagen I was increased in cells treated with 2 and $10 \mathrm{ng} / \mathrm{mL}$ TNF- $\alpha$ after 72 h. Secretion of interleukin (IL)- 6 and IL-8 was promoted with 10 and $50 \mathrm{ng} / \mathrm{mL}$ TNF- $\alpha$, while that of IL- $1 \beta$ or transforming growth factor- $\beta$ was unaffected. Slug and Smad 2 were upregulated by TNF- $\alpha$ after $72 \mathrm{~h}$. The Smad pathway was activated most strongly with $10 \mathrm{ng} / \mathrm{mL}$ TNF- $\alpha$ and Slug pathway activation was positively correlated with the concentration of TNF- $\alpha$.

Conclusions: Sustained $10 \mathrm{ng} / \mathrm{mL}$ TNF- $\alpha$ stimulation induced the EMT and pro-fibrogenesis phenotype resembling BPS/IC in SV-HUC-1 cells. Minor inflammatory stimulation induced the pro-fibrogenesis phenotype while severe inflammatory stimulation was more likely to produce significant EMT changes. Different degrees of activation of the Slug and Smad pathways may underlie this phenomenon.

Keywords: Urothelial cell model; epithelial to mesenchymal transition (EMT); pro-fibrogenesis phenotype; bladder fibrosis; bladder pain syndrome/interstitial cystitis (BPS/IC)

Submitted May 01, 2021. Accepted for publication Sep 22, 2021.

doi: $10.21037 /$ tau-21-392

View this article at: https://dx.doi.org/10.21037/tau-21-392 


\section{Introduction}

Bladder pain syndrome/interstitial cystitis (BPS/IC) is a non-infective disease with clinical presentations of chronic pelvic pain, urinary frequency, and nocturia, and which mainly occurs in women $(1,2)$. As the typical symptoms of BPS/IC cause intense physical and mental suffering and lead to restricted social and daily life, efforts made to understand and treat BPS/IC have largely focused on pain and urinary dysfunction $(3,4)$. The treatments are varied and target the symptoms patients find most bothersome, but none are universally effective (3).

Bladder fibrosis is common in BPS/IC and is induced by chronic inflammation (5). The severity of bladder fibrosis is one of the important reasons about the increased urinary frequency and decreased bladder capacity (6), and therefore treatment of bladder tissue fibrosis may be a promising therapeutic target for BPS/IC (7). The epithelial to mesenchymal transition (EMT) and pro-fibrogenesis phenotype in bladder urothelial cells of BPS/IC plays an important role in the bladder fibrosis of this disease (8). However, studies of urothelial EMT and bladder fibrosis of BPS/IC are limited. Lack of a urothelial cell model is one reason.

Suitable in vitro models are needed to investigate the urothelial EMT and pro-fibrogenesis phenotype in BPS/IC. In this study, we explored the EMT and pro-fibrogenesis phenotype in bladder tissue of BPS/IC patients, and attempted to establish an EMT and pro-fibrogenesis phenotype model by chronic inflammatory stimulation of bladder urothelial cells. We present the following article in accordance with the MDAR reporting checklist (available at https://dx.doi.org/10.21037/tau-21-392).

\section{Methods}

\section{Ethics approval and consent to participate}

The study was conducted in accordance with the Declaration of Helsinki (as revised in 2013). This research was approved by the Ethics Committee of Ruijin Hospital, Shanghai Jiao Tong University School of Medicine (No. 202134). Informed consent was obtained from all individual participants included in the study.

\section{Bladder tissue acquisition}

BPS/IC patients were diagnosed according to the updated American Urological Association criteria (9). For patients (four females were retrospective collected, aged $37-$ 62 years; three non-Hunner ICs and one Hunner IC; bladder capacities between $200-380 \mathrm{~mL}$; all patients did not previously receive IC-related treatment) who had undergone cystoscopy and bladder biopsies in the past 2 years, the bladder tissue samples were fixed in $10 \%$ buffered formalin and embedded in paraffin. Histological examination had previously diagnosed BPS/IC and the remaining tissue was used in this study. Normal bladder tissue was obtained from patients who underwent transurethral resection of prostate or benign bladder tumors.

\section{Histopathologic staining}

The embedded bladder tissues were cut into $5 \mu \mathrm{m}$ thick sections and stained with hematoxylin and eosin (HE) or Masson's trichrome. Immunohistochemistry (IHC) was performed to assess protein expression as described previously (10) with the following primary antibodies: antiE-cadherin (Cell Signaling Technology, \#14472, USA; 1:200), anti-vimentin (Cell Signaling Technology, \#5741; 1:200); anti-TNF- $\alpha$ (Proteintech, \#60291-1-lg, USA; 1:500); anti-TNF receptor 1 (Proteintech, \#60192-1-lg, USA; 1:200), and anti-collagen I (Abcam, \#ab138492, USA; 1:500). Positive staining was revealed with Vector DAB Substrate Kit (Vector Laboratories, \#SK-4100, USA) and nuclei were counterstained with hematoxylin.

\section{Cell culture and stimulation}

The SV-HUC-1 cell line was purchased from Fuheng Biology Company (Shanghai, China). Cell line authentication by STR profiling showed complete matching to SV-HUC-1 in ATCC (No. CRL-9520). The culturing conditions included F12K medium (Gibco, \#21127022, USA) containing 10\% fetal bovine serum (Gibco, \#10099, Australia).

SV-HUC-1 cells were cultured with serum-free F12K medium containing 2, 10, or $50 \mathrm{ng} / \mathrm{mL}$ of tumor necrosis factor (TNF)- $\alpha$ (Invitrogen, \#RTNFAI, USA). SV-HUC-1 cells cultured with only serum-free $\mathrm{F} 12 \mathrm{~K}$ served as a control. The medium was refreshed every $24 \mathrm{~h}$. Cells were harvested after 24,48 , and $72 \mathrm{~h}$ of culture.

\section{Invasion assay}

A 24-well Boyden chamber with an $8-\mu \mathrm{m}$ pore size polycarbonate membrane (Millipore, USA) was used for 
the invasion assay. A total of $1 \times 10^{5}$ pretreated cells were resuspended in $100 \mu \mathrm{L}$ serum-free $\mathrm{F} 12 \mathrm{~K}$ medium and added to the upper compartment of the chamber. The lower compartment was filled with $600 \mu \mathrm{L}$ of $\mathrm{F} 12 \mathrm{~K}$ medium supplemented with $10 \%$ FBS. After incubation for $48 \mathrm{~h}$ at $37^{\circ} \mathrm{C}$, the SV-HUC-1 cells remaining inside the upper chamber were wiped off with a cotton-tipped swab. Cells that adhered to lower membranes were stained with $0.1 \%$ crystal violet after fixation with methanol and imaged under a light microscope (Eclipse E600, Nikon, Japan).

\section{Migration array}

When cells in different groups were grown to near 100\% confluence in six-well plates, a micropipette tip was used to make a wound. Then, cells were incubated with serum-free F12K medium containing $0,2,10$, or $50 \mathrm{ng} / \mathrm{mL}$ TNF- $\alpha$. Wound healing was observed after $72 \mathrm{~h}$. A phase-contrast microscope (Olympus, Japan) was used to take photographs. The Fiji version of ImageJ software (https://fiji.sc/wiki/ index.php/Fiji) was used to analyze wound closure.

\section{Western blotting}

Different groups of SV-HUC-1 cells were harvested, washed with ice-cold phosphate-buffered saline (PBS), and lysed in radioimmunoprecipitation buffer (TNT Bio, \#AKR-190, China). A bicinchoninic acid protein assay (Pierce, \#23252, Rockford, USA) was used to assess the concentrations of the precipitated proteins in the cell lysates. Then, each sample was diluted to equal concentrations, boiled for $5 \mathrm{~min}$, and separated by $8 \%$ SDS-PAGE. Afterwards, the proteins were transferred to PVDF membrane and 5\% milk was used to block the membrane at room temperature for $1 \mathrm{~h}$. The membranes were incubated overnight at $4{ }^{\circ} \mathrm{C}$ with the following primary antibodies (1:1,000): vimentin (Cell Signaling Technology, \#5741), E-cadherin (Cell Signaling Technology, \#14472), collagen I (Abcam, \#ab138492; 1:500), Slug (Cell Signaling Technology, \#9585), Smad2 (Proteintech, \#12570-1-AP, USA), phospho-Smad2 (Cell Signaling Technology, \#18338, USA); TGF- $\beta$ (Cell Signaling Technology, \#3709, USA); and $\beta$-actin (Medical \& Biological Laboratories, \#M177-3, Japan). Following three washes with PBS + Tween-20, membranes were incubated with the corresponding secondary antibodies for $1 \mathrm{~h}$ at room temperature followed by washing and staining. Protein bands were detected using the Immobilon western chemiluminescence HRP substrate kit (Takara, \#T7101, China). $\beta$-actin served as the loading control.

\section{Enzyme-linked immunosorbent assay (ELISA)}

Supernatants were collected from the four groups after the third $24 \mathrm{~h}$ of culture. The levels of interleukin (IL)-1 $\beta$, IL-6, IL-8, and GF- $\beta$ in the supernatant were determined using ELISA kits (R\&D Systems, \#DLB50, \#D6050, \#D8000C, \#DB100B, UK) according to the manufacturer's instructions. Each sample was measured in triplicate with a microplate reader (Bio-Rad, USA).

\section{Statistical analysis}

All experiments were performed in triplicate and results are presented as the mean \pm standard error of the mean. Analysis of variance (ANOVA) with post-hoc Tukey's test for multiple comparisons was performed using IBM SPSS Statistics 23 (IBM Corp., Armonk, NY, USA). Graphs were generated using GraphPad Prism 6 (GraphPad Software, California, USA). $\mathrm{P}<0.05$ was considered statistically significant.

\section{Results}

Bladder tissue of BPS/IC showed obvious urothelial EMT changes and pro-fibrotic phenotype

Previous studies have shown that fibrosis and urothelial EMT changes occur in the bladder tissue of BPS/IC $(5,8)$; our histopathologic results confirmed these phenomena. As shown in Figure 1, HE staining showed obvious mucosal edema, perivascular leukocyte infiltration, and petechial hemorrhage in bladder tissue of BPS/IC compared with normal bladder tissue. Normal bladder tissue showed hypodense thin collagen fibers in the submucosa by Masson staining. High density crude collagen fibers were found in the mucosa and submucosa of BPS/IC bladder tissue. High-expression of TNF- $\alpha$ and TNF receptor were also found in the bladder of BPS/IC compared to that in normal bladder. E-cadherin and vimentin were used as epithelial and mesenchymal markers, respectively (11). Normal bladder exhibited high expression of E-cadherin and microexpression of vimentin in urothelial cells. By contrast, BPS/ IC bladder showed reduced expression of E-cadherin but high expression of vimentin in urothelial cells. Extracellular matrix (ECM) deposition is common in fibrotic diseases, 

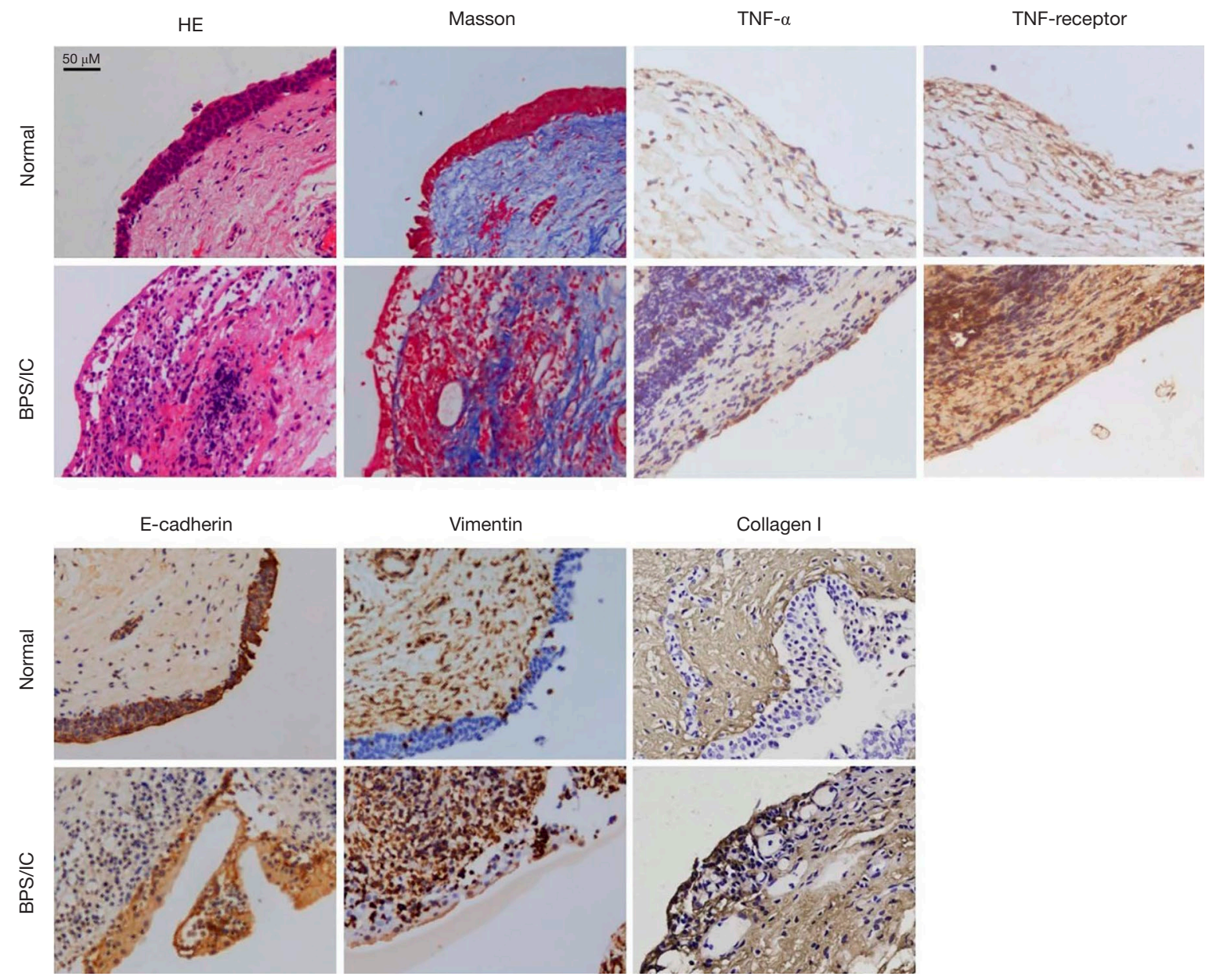

Figure 1 Histopathologic results of bladder tissues in BPS/IC and normal patients including HE, Masson, vimentin, E-cadherin, TNF- $\alpha$, and collagen I. Compared with normal bladder tissue, that of BPS/IC patients showed obvious mucosal edema and perivascular leukocyte infiltration (HE), overexpression of collagen fibers (Masson), high-expression of E-cadherin and TNF- $\alpha$ receptor, micro-expression of vimentin, and collagen I deposition. BPS/IC, bladder pain syndrome/interstitial cystitis; TNF- $\alpha$, tumor necrosis factor $\alpha$; HE, hematoxylin and eosin.

and excessive collagen I formation is regarded as the classic pro-fibrogenesis phenotype (12-14). IHC staining showed excessive formation of collagen I in urothelial cells of BPS/ IC compared with those in the normal bladder. These results demonstrated that TNF- $\alpha$ played an important role in the bladder of BPS/IC, and that BPS/IC urothelial cells presented typical EMT changes and a pro-fibrogenesis phenotype.

\section{Chronic inflammation induced the EMT in SV-HUC-1 cells}

TNF- $\alpha$ at $10 \mathrm{ng} / \mathrm{mL}$ is widely used as an inflammatory stimulator in experimental cell models (15-17). To explore the effects of different concentrations of TNF- $\alpha, 2,10$, and $50 \mathrm{ng} / \mathrm{mL}$ TNF- $\alpha$ were tested in our study, which presented in Figure 2. As Figure 2A, SV-HUC-1 cells treated with 10 or $50 \mathrm{ng} / \mathrm{mL}$ TNF- $\alpha$ for $72 \mathrm{~h}$ showed significant morphological changes, from a round epithelial shaped to a spindle-like mesenchymal form, while cells treated with $2 \mathrm{ng} / \mathrm{mL}$ TNF- $\alpha$ showed slight changes in morphology compared with the control. In Figure $2 A, 2 C$, Transwell assays displayed cell invasive ability was greatest following treatment with $10 \mathrm{ng} / \mathrm{mL}$ TNF- $\alpha(10$ vs. $50 \mathrm{ng} / \mathrm{mL}$, $\mathrm{P}=0.023 ; 10$ vs. $2 \mathrm{ng} / \mathrm{mL}, \mathrm{P}<0.001 ; 10$ vs. $0 \mathrm{ng} / \mathrm{mL}, \mathrm{P}<0.001$ ) while invasion was gradually reduced following treatment 
A

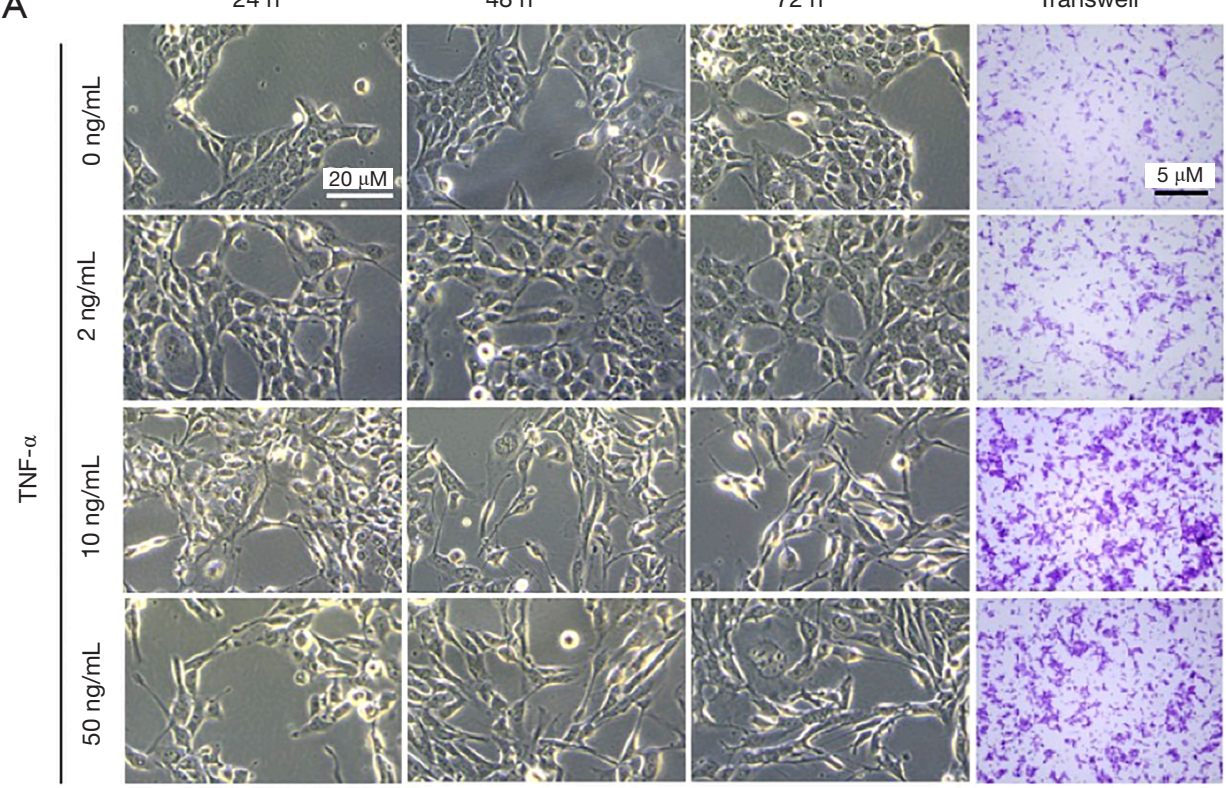

B

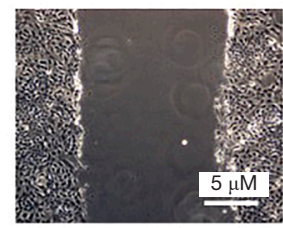

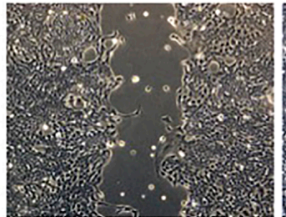

$0 \mathrm{ng} / \mathrm{mL}$

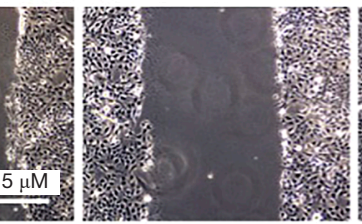

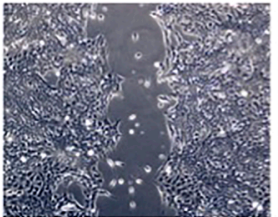

$2 \mathrm{ng} / \mathrm{mL}$

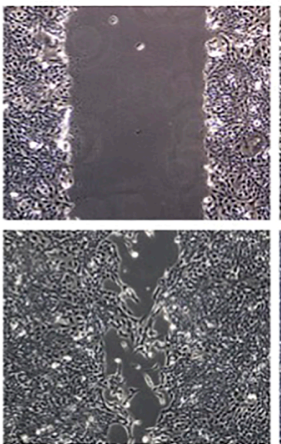

$10 \mathrm{ng} / \mathrm{mL}$

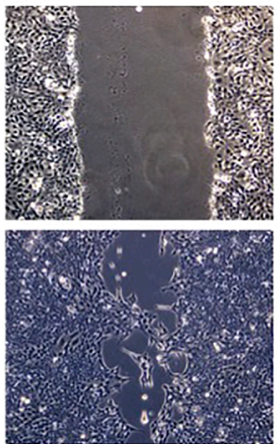

$50 \mathrm{ng} / \mathrm{mL}$

TNF- $\alpha$

C

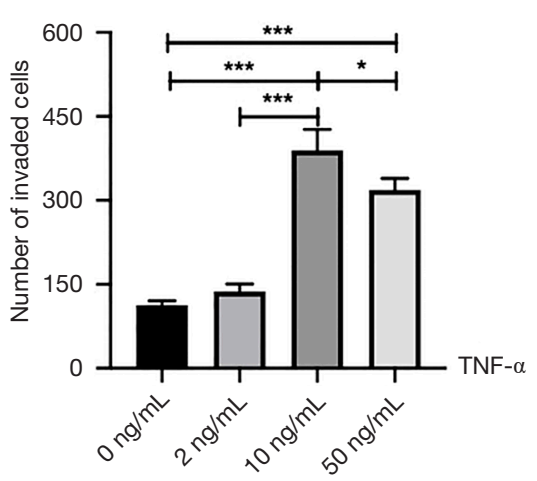

D

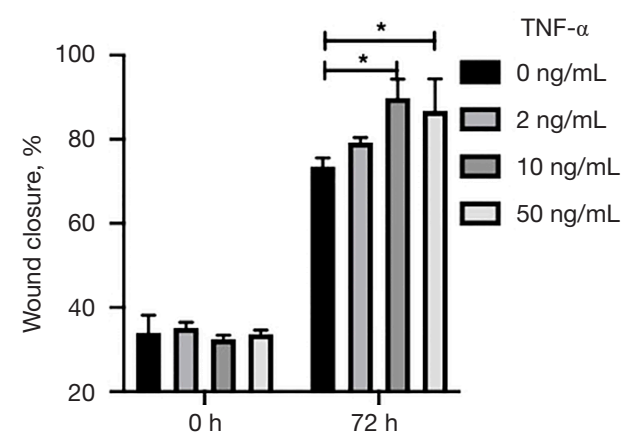

Figure 2 Morphological and behavioral changes of SV-HUC-1 cells treated with different concentrations of TNF- $\alpha$. (A) Morphological changes of SV-HUC-1 cells with $0,2,10$, or $50 \mathrm{ng} / \mathrm{mL}$ TNF- $\alpha$ treatment after 24, 48, and $72 \mathrm{~h}$ of culture. Transwell assay showed the invasion capacity changes of SV-HUC-1 cells treated with $0,2,10$, or $50 \mathrm{ng} / \mathrm{mL}$ TNF- $\alpha$ after $48 \mathrm{~h}$ of culture. (B) Migratory capacity changes of SVHUC-1 cells treated with $0,2,10$, or $50 \mathrm{ng} / \mathrm{mL} \mathrm{TNF}-\alpha$ after $72 \mathrm{~h}$ of culture. (C) Statistical analysis of Transwell assay. (D) Statistical analysis of migration array. ***, $\mathrm{P}<0.001$; * $\mathrm{P}<0.05$ (analyzed using Tukey's multiple comparisons test, $\mathrm{n}=3$ per group). TNF- $\alpha$, tumor necrosis factor $\alpha$. 


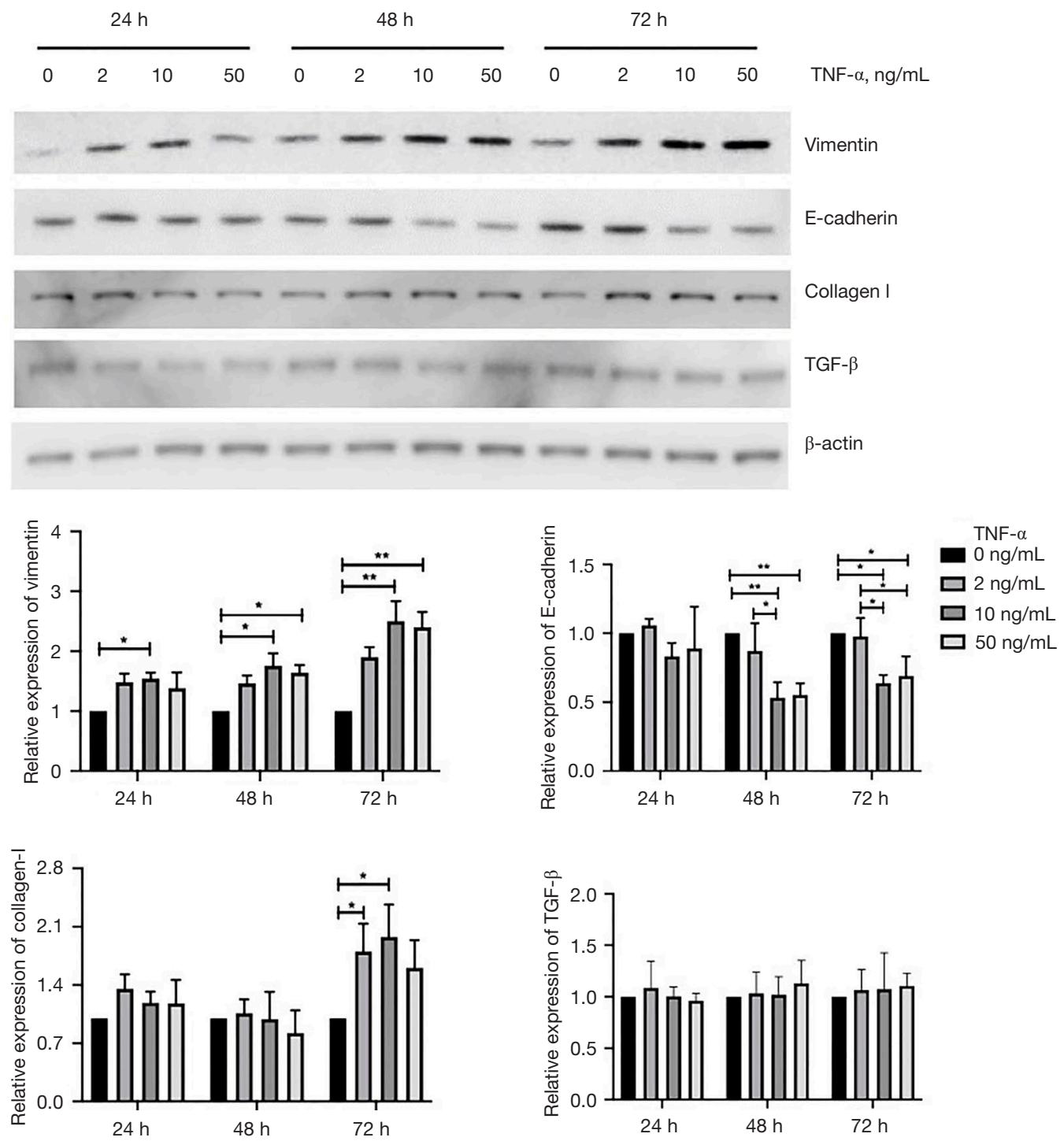

Figure 3 Changes in vimentin, E-cadherin, collagen I, and TGF- $\beta$ expression in SV-HUC-1 cells treated with different concentrations of TNF- $\alpha$. SV-HUC-1 cells were treated with $0,2,10$, or $50 \mathrm{ng} / \mathrm{mL}$ TNF- $\alpha$. After 24, 48, and $72 \mathrm{~h}$ of culture, western blotting was used to assess the levels of vimentin, E-cadherin, collagen I, TGF- $\beta$, and $\beta$-actin. Semiquantitative analysis is also presented. **, $\mathrm{P}<0.01$; *, $\mathrm{P}<0.05$ (analyzed using Tukey's multiple comparisons test, $\mathrm{n}=3$ per group). TNF- $\alpha$, tumor necrosis factor $\alpha$.

with 50, 2 , and $0 \mathrm{ng} / \mathrm{mL}$ TNF- $\alpha(50$ vs. $2 \mathrm{ng} / \mathrm{mL}, \mathrm{P}<0.001$; 50 vs. $0 \mathrm{ng} / \mathrm{mL}, \mathrm{P}<0.001 ; 2$ vs. $0 \mathrm{ng} / \mathrm{mL}, \mathrm{P}=0.557)$. In Figure $2 B, 2 D, \mathrm{SV}-\mathrm{HUC}-1$ migratory ability was significantly enhanced in the 10 and $50 \mathrm{ng} / \mathrm{mL}$ TNF- $\alpha$ groups compared to that in the control $(10$ vs. $0 \mathrm{ng} / \mathrm{mL}, \mathrm{P}=0.014 ; 50$ vs. $0 \mathrm{ng} / \mathrm{mL}, \mathrm{P}=0.044)$. SV-HUC-1 cells treated with $2 \mathrm{ng} / \mathrm{mL}$ $\mathrm{TNF}-\alpha$ showed no difference in migratory ability compared to the control group $(\mathrm{P}=0.654)$.

As shown in Figure 3, SV-HUC-1 cells treated with $2 \mathrm{ng} / \mathrm{mL}$ TNF- $\alpha$ showed a moderate increase in vimentin expression compared with the control group with increasing time, but the differences were not significant. SV-HUC-1 cells treated with 10 and $50 \mathrm{ng} / \mathrm{mL}$ TNF- $\alpha$ showed increased expression of vimentin compared with control cells after the second $24 \mathrm{~h}$ of culture $(10 \mathrm{vs}$. $0 \mathrm{ng} / \mathrm{mL}, \mathrm{P}=0.020 ; 50$ vs. $0 \mathrm{ng} / \mathrm{mL}, \mathrm{P}=0.044)$ and the third $24 \mathrm{~h}$ of culture $(10$ vs. $0 \mathrm{ng} / \mathrm{mL}, \mathrm{P}=0.009 ; 50$ vs. $0 \mathrm{ng} / \mathrm{mL}$, $\mathrm{P}=0.006)$, and there was no difference between themselves. SV-HUC-1 cells treated with $2 \mathrm{ng} / \mathrm{mL}$ TNF- $\alpha$ showed similar E-cadherin expression as the control cells, whereas 

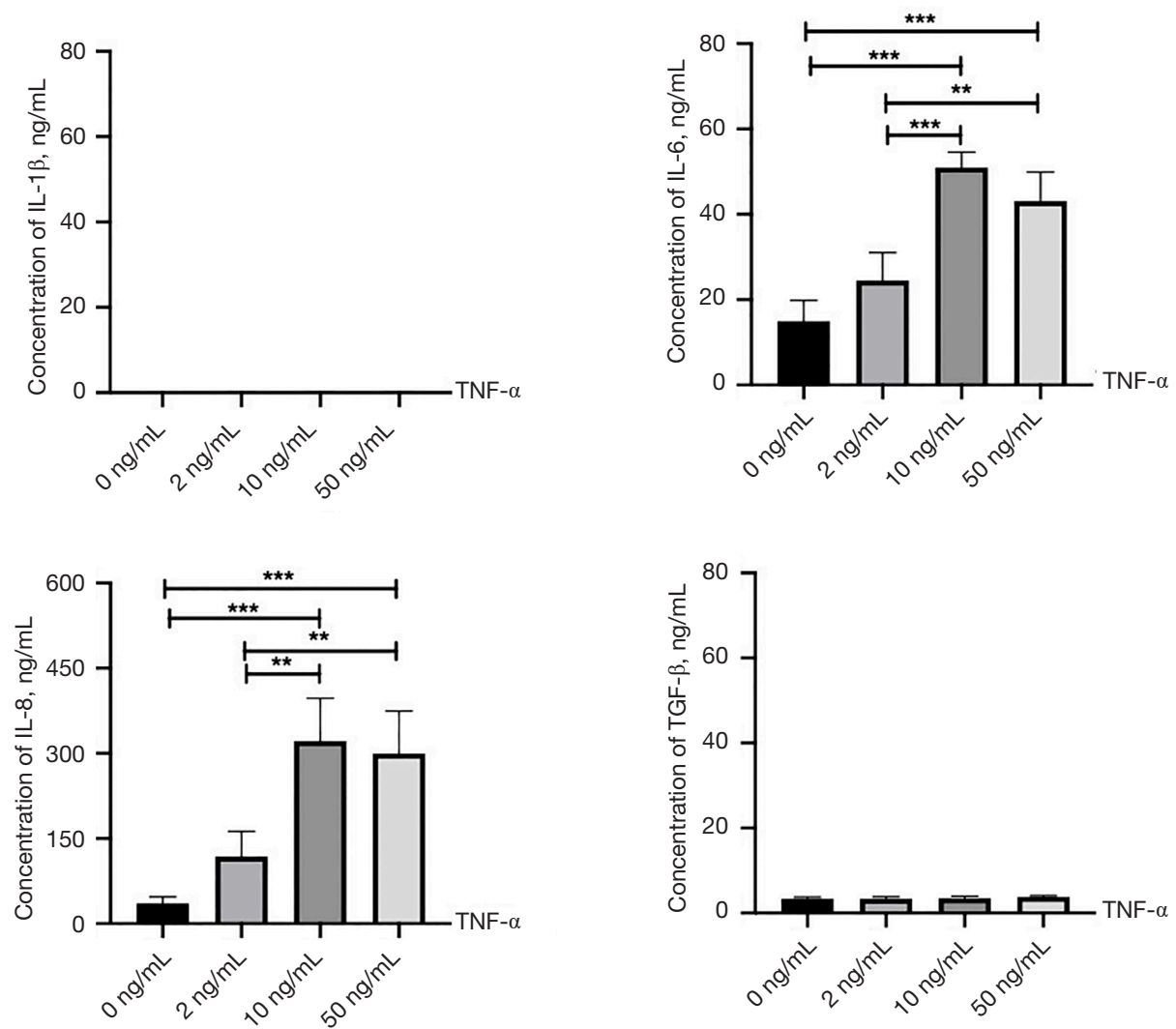

Figure 4 Changes in IL-1 $\beta$, IL-6, IL-8, and TGF- $\beta$ secretion in urothelial cells treated with different concentrations of TNF- $\alpha$. SV-HUC-1 cells were treated with $0,2,10$, or $50 \mathrm{ng} / \mathrm{mL}$ TNF- $\alpha$. After the third $24 \mathrm{~h}$ of culture, ELISA was used to detect the concentrations of IL$1 \beta$, IL-6, IL-8, and TGF- $\beta$ in the supernatant. ${ }^{* *}, \mathrm{P}<0.001$; ${ }^{* *}, \mathrm{P}<0.01$ (analyzed using Tukey's multiple comparisons test, $\mathrm{n}=3$ per group). TNF- $\alpha$, tumor necrosis factor $\alpha$.

SV-HUC- 1 cells treated with 10 or $50 \mathrm{ng} / \mathrm{mL}$ TNF- $\alpha$ showed less E-cadherin expression after the second $24 \mathrm{~h}$ of culture (10 vs. $0 \mathrm{ng} / \mathrm{mL}, \mathrm{P}=0.002 ; 10$ vs. $2 \mathrm{ng} / \mathrm{mL}, \mathrm{P}=0.016$; 50 vs. $0 \mathrm{ng} / \mathrm{mL}, \mathrm{P}=0.002 ; 50$ vs. $2 \mathrm{ng} / \mathrm{mL}, \mathrm{P}=0.023)$ and the third $24 \mathrm{~h}$ of culture $(10 v s .0 \mathrm{ng} / \mathrm{mL}, \mathrm{P}=0.011 ; 10 v s$. $2 \mathrm{ng} / \mathrm{mL}, \mathrm{P}=0.015 ; 50$ vs. $0 \mathrm{ng} / \mathrm{mL}, \mathrm{P}=0.025 ; 50$ vs. $2 \mathrm{ng} / \mathrm{mL}, \mathrm{P}=0.036$ ), but no difference between themselves. These data suggested that sustained TNF- $\alpha$ stimulation could induce the EMT in SV-HUC-1 cells.

\section{Chronic inflammation induced a pro-fibrogenesis phenotype in SV-HUC-1 cells}

The pro-fibrogenesis phenotype was assessed by excessive collagen formation and pro-fibrotic cytokine production. As presented in Figure 3, all groups treated with TNF- $\alpha$ showed increased production of collagen I with increasing time, and groups treated with 2 or $10 \mathrm{ng} / \mathrm{mL}$ TNF- $\alpha$ showed significantly increased collagen I production compared with the other two groups at the third $24 \mathrm{~h}$ of culture ( 2 vs. $0 \mathrm{ng} / \mathrm{mL}, \mathrm{P}=0.045 ; 10$ vs. $0 \mathrm{ng} / \mathrm{mL}, \mathrm{P}=0.019)$. Interestingly, SV-HUC-1 cells treated with $50 \mathrm{ng} / \mathrm{mL}$ TNF- $\alpha$ showed no statistical difference compared to control cells, suggesting that only the lower concentration of TNF- $\alpha$ could increase collagen I production. TGF- $\beta$ is a major inducer of the EMT in epithelial cells and of tissue fibrosis (18). However, as presented in Figure 3, all groups treated with TNF- $\alpha$ showed decreased production of TGF- $\beta$ with increasing time with no difference among them. IL- $1 \beta$, IL- 6 , and IL- 8 are considered pro-fibrotic cytokines (19-22); we thus investigated the concentration of each cytokine at the end of the third $24 \mathrm{~h}$ of culture. As presented in Figure 4, no IL- $1 \beta$ and low TGF- $\beta$ production were observed in SV-HUC-1 cells before and after TNF- $\alpha$ treatment. However, SV-HUC-1 cells treated with 10 or $50 \mathrm{ng} / \mathrm{mL}$ TNF- $\alpha$ exhibited high levels of IL- 6 compared 

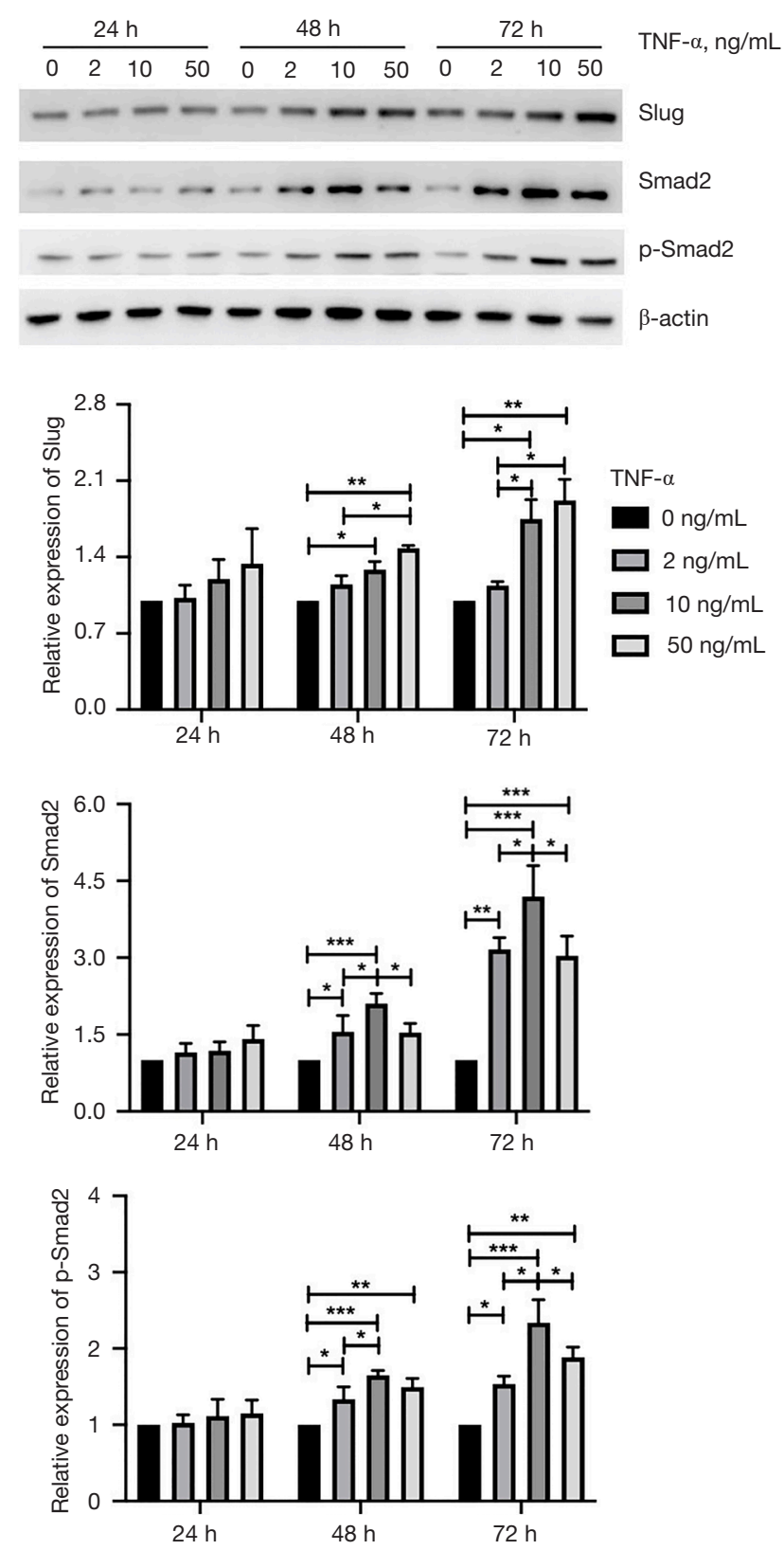

Figure 5 Changes in Slug and Smad2 expression in SV-HUC-1 cells treated with different concentrations of TNF- $\alpha$. SV-HUC-1 cells were treated with $0,2,10$, or $50 \mathrm{ng} / \mathrm{mL}$ TNF- $\alpha$. After 24,48 , and $72 \mathrm{~h}$ of culture, western blotting was used to assess the levels of Slug, Smad2, phospho-Smad2, and $\beta$-actin. Semiquantitative analysis is also presented. ${ }^{* *}, \mathrm{P}<0.001 ;{ }^{* *}, \mathrm{P}<0.01 ;{ }^{*}, \mathrm{P}<0.05$ (analyzed using Tukey's multiple comparisons test, $\mathrm{n}=3$ per group). TNF- $\alpha$, tumor necrosis factor $\alpha$. with control cells (10 vs. $0 \mathrm{ng} / \mathrm{mL}, \mathrm{P}<0.001 ; 50$ vs. $0 \mathrm{ng} / \mathrm{mL}$, $\mathrm{P}<0.001$ ) and with the group treated with $2 \mathrm{ng} / \mathrm{mL}$ TNF- $\alpha$ (10 vs. $2 \mathrm{ng} / \mathrm{mL}, \mathrm{P}<0.001 ; 50$ vs. $2 \mathrm{ng} / \mathrm{mL}, \mathrm{P}=0.003)$. SVHUC- 1 cells treated with 10 or $50 \mathrm{ng} / \mathrm{mL}$ TNF- $\alpha$ also showed high levels of IL-8 compared control cells (10 vs. $0 \mathrm{ng} / \mathrm{mL}, \mathrm{P}<0.001 ; 50$ vs. $0 \mathrm{ng} / \mathrm{mL}, \mathrm{P}<0.001)$ and with the group treated with $2 \mathrm{ng} / \mathrm{mL}$ TNF- $\alpha(10$ vs. $2 \mathrm{ng} / \mathrm{mL}$, $\mathrm{P}=0.002 ; 50$ vs. $2 \mathrm{ng} / \mathrm{mL}, \mathrm{P}=0.004)$. These results indicated that TNF- $\alpha$ treatment could induce the pro-fibrogenesis phenotype including increased ECM deposition, as well as high levels of IL-6 and IL-8 in urothelial cells.

\section{The Slug and Smad pathways are involved in the EMT and pro-fibrogenesis phenotype in SV-HUC-1 cells}

Slug and Smad are two classic pathways associated with the EMT and fibrosis $(23,24)$. As shown in Figure 5, expression of Slug was significantly increased in cells treated with 10 or $50 \mathrm{ng} / \mathrm{mL}$ compared with control cells or the group treated with $2 \mathrm{ng} / \mathrm{mL}$ after the second $24 \mathrm{~h}$ of culture (10 vs. $0 \mathrm{ng} / \mathrm{mL}, \mathrm{P}=0.037 ; 50$ vs. $0 \mathrm{ng} / \mathrm{mL}, \mathrm{P}=0.003$; 50 vs. $2 \mathrm{ng} / \mathrm{mL}, \mathrm{P}=0.019)$ and third $24 \mathrm{~h}$ of culture $(10$ vs. $0 \mathrm{ng} / \mathrm{mL}, \mathrm{P}=0.016 ; 10$ vs. $2 \mathrm{ng} / \mathrm{mL}, \mathrm{P}=0.048 ; 50$ vs. $0 \mathrm{ng} / \mathrm{mL}, \mathrm{P}=0.004 ; 50$ vs. $2 \mathrm{ng} / \mathrm{mL}, \mathrm{P}=0.010$ ), but there was no statistical difference between these two groups. Cells treated with $2 \mathrm{ng} / \mathrm{mL} \mathrm{TNF}-\alpha$ did not show any change in the Slug pathway. These results suggest TNF- $\alpha$ induction of the Slug pathway is linearly correlated with the concentration of TNF- $\alpha$ from 0 to $50 \mathrm{ng} / \mathrm{mL}$. Smad2 is a key protein in the classic Smad pathway, where phosphoSmad2 is the active form. Expression of Smad2 in cells treated with 2 and $10 \mathrm{ng} / \mathrm{mL}$ was higher than in the control after the second $24 \mathrm{~h}$ of culture $(2 \mathrm{vs} .0 \mathrm{ng} / \mathrm{mL}, \mathrm{P}=0.047 ; 10$ vs. $0 \mathrm{ng} / \mathrm{mL}, \mathrm{P}<0.001)$ and the third $24 \mathrm{~h}$ of culture ( 2 vs. $0 \mathrm{ng} / \mathrm{mL}, \mathrm{P}<0.001 ; 10$ vs. $0 \mathrm{ng} / \mathrm{mL}, \mathrm{P}<0.001)$. Expression of Smad2 in cells treated with $10 \mathrm{ng} / \mathrm{mL}$ was the highest of the three TNF- $\alpha$-treated groups after the second $24 \mathrm{~h}$ of culture (10 vs. $2 \mathrm{ng} / \mathrm{mL}, \mathrm{P}=0.046 ; 10$ vs. $50 \mathrm{ng} / \mathrm{mL}, \mathrm{P}=0.042)$ and third $24 \mathrm{~h}$ of culture $(10 v s .2 \mathrm{ng} / \mathrm{mL}, \mathrm{P}=0.041 ; 10 v s$. $50 \mathrm{ng} / \mathrm{mL}, \mathrm{P}=0.024)$. Expression of phospho-Smad2 in cells treated with 2 and $10 \mathrm{ng} / \mathrm{mL}$ was higher than in control cells after the second $24 \mathrm{~h}(2 v s .0 \mathrm{ng} / \mathrm{mL}, \mathrm{P}=0.018 ; 2 v s$. $10 \mathrm{ng} / \mathrm{mL}, \mathrm{P}=0.025 ; 10$ vs. $0 \mathrm{ng} / \mathrm{mL}, \mathrm{P}<0.001)$ and third $24 \mathrm{~h}$ of culture $(2$ vs. $0 \mathrm{ng} / \mathrm{mL}, \mathrm{P}=0.021 ; 10$ vs. $0 \mathrm{ng} / \mathrm{mL}$, 


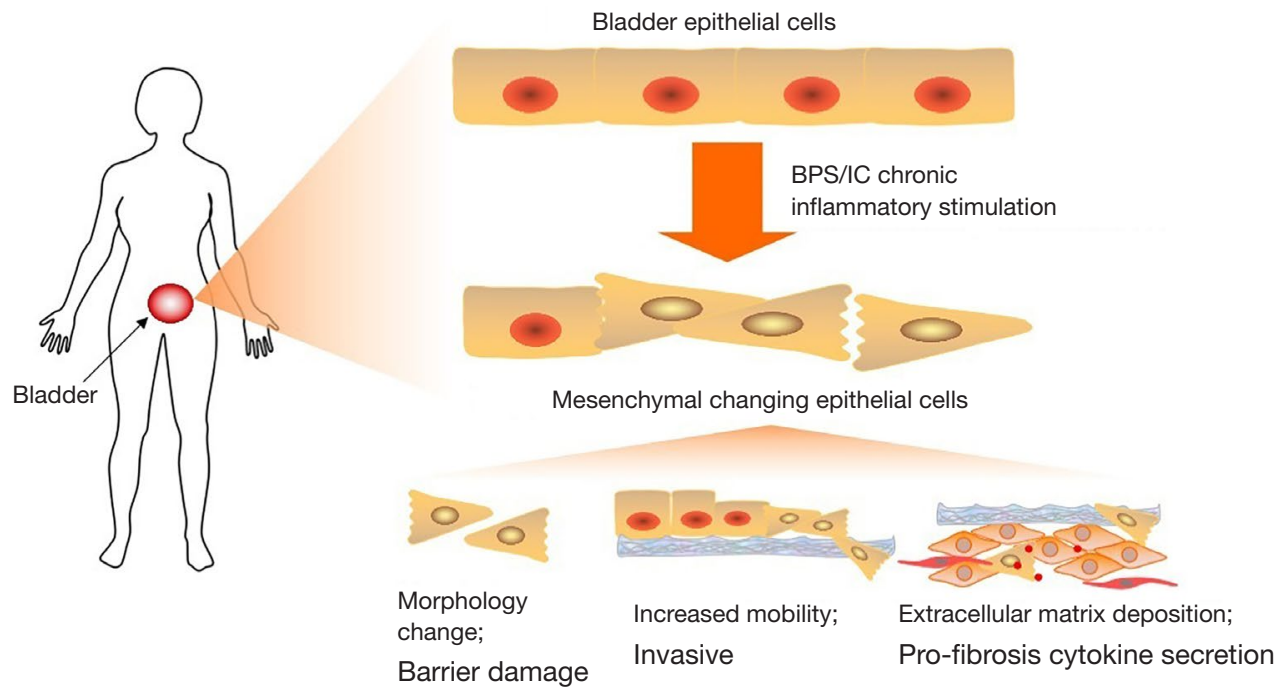

Figure 6 Hypothesis of the mechanism of inflammation, EMT, and fibrosis in the BPS/IC bladder. EMT, epithelial to mesenchymal transition; BPS/IC, bladder pain syndrome/interstitial cystitis.

$\mathrm{P}<0.001)$. Expression of phospho-Smad2 in cells treated with $10 \mathrm{ng} / \mathrm{mL}$ was the highest of the three TNF- $\alpha$ treated groups after the second $24 \mathrm{~h}$ of culture $(10 \mathrm{vs}$. $2 \mathrm{ng} / \mathrm{mL}, \mathrm{P}=0.025 ; 10$ vs. $50 \mathrm{ng} / \mathrm{mL}, \mathrm{P}=0.341)$ and third $24 \mathrm{~h}$ of culture $(10 v s .2 \mathrm{ng} / \mathrm{mL}, \mathrm{P}=0.002 ; 10 v s .50 \mathrm{ng} / \mathrm{mL}$, $\mathrm{P}=0.049$ ). These results suggest the Slug and Smad pathways are involved in TNF- $\alpha$-induced EMT and pro-fibrogenesis phenotype in urothelial cells. A lower concentration of TNF- $\alpha$ was more likely to activate the Smad pathway, and a higher concentration of TNF- $\alpha$ activated the Slug pathway.

\section{Discussion}

This study suggests that increased TNF- $\alpha$ production and TNF receptor expression, EMT, and a pro-fibrogenesis phenotype occur in bladder urothelial cells of BPS/IC; this phenomenon could be reproduced by sustained TNF- $\alpha$ stimulation of SV-HUC-1 cells, which could be useful as an experimental EMT and pro-fibrogenesis model in urothelial cells resembling BPS/IC. A concentration of $10 \mathrm{ng} / \mathrm{mL}$ TNF- $\alpha$ was necessary to induce EMT changes and the pro-fibrogenesis phenotype simultaneously. We also found that different concentrations of TNF- $\alpha$ could induce different phenotypes; this supported the notion that minor inflammatory stimulation induced the profibrogenesis phenotype and severe inflammatory stimulation was more likely to produce significant EMT changes. This could explain the different clinical characteristics in
non-Hunner and Hunner type BPS/IC; different levels of activation of the Slug and Smad pathways may underlie this phenomenon.

The precise etiology of BPS/IC is not clearly understood (3). Bladder epithelium barrier defects and local inflammation are two widely accepted classic mechanisms of BPS/IC $(25,26)$. Bladder fibrosis is also common in BPS/ IC (5-7). However, there is no clear theory to connect these aspects. Numerous studies have shown an association between inflammation and the EMT (11), the EMT and fibrosis (27), and inflammation and fibrosis (28). Based on our study and previous reports, we propose a comprehensive hypothesis of the inflammation, EMT, and fibrosis in BPS/IC in Figure 6. Long-term and chronic inflammatory stimulation induced EMT changes in urothelial cells. As morphology of urothelial cells changed and migratory capacity increased, the bladder epithelium barrier was damaged. This could increase permeability of the bladder to urinary cations, resulting in diffusion of potassium into bladder tissue and the induction of symptoms at a relatively early stage. EMT urothelial cells may invade into the submucosa and muscular layer of the bladder. In this process, EMT urothelial cells continue to produce ECM. Moreover, pro-fibrosis cytokines such as IL-6 and IL-8 are highly secreted by urothelial cells, which have also been shown to be present in increased concentrations in the serum of BPS/IC patients (29). These cytokines induced ECM deposition in mesenchymal cells and fibroblasts, 
and promoted the production of pro-fibrosis cytokines such TGF- $\beta$ by immune cells. These results support the hypothesis that chronic inflammation can induce the urothelial EMT and a pro-fibrogenesis phenotype in BPS/IC.

As researchers developed a more profound understanding of BPS/IC, two different classifications, non-Hunner or Hunner type BPS/IC, were proposed according to clinical characteristics $(6,26)$. Non-Hunner type BPS/IC exhibits more obvious fibrosis, whereas Hunner-type BPS/IC shows severe inflammation and urothelial denudation $(6,7)$. It was impressive that our study showed that 2 or $10 \mathrm{ng} / \mathrm{mL}$ TNF- $\alpha$ could induce urothelial cells to produce excessive collagen I, but no statistical difference was found between the 0 and $50 \mathrm{ng} / \mathrm{mL}$ TNF- $\alpha$ groups. Moreover, $2 \mathrm{ng} / \mathrm{mL}$ TNF- $\alpha$ had no effect on the EMT, suggesting that, in urothelial cells, lower inflammatory stimulation induced the pro-fibrogenesis phenotype, moderate inflammatory stimulation induced both the pro-fibrogenesis phenotype and the EMT, and higher inflammatory stimulation induced significant EMT changes. Some Hunner-type BPS/IC patients show inflammation as well as fibrosis in the bladder, indicating there is no international consensus on the clinical phenotypes of non-Hunner and Hunner type BPS/IC (30). However, this could be explained by the results of our study as moderate inflammatory stimulation (e.g., $10 \mathrm{ng} / \mathrm{mL}$ TNF- $\alpha$ ) could induce EMT changes and ECM deposition in SV-HUC-1 cells. In Hunner type BPS/IC, when the bladder undergoes severe inflammation, it is subjected to different degrees of inflammation for a long period of time. Hunner type BPS/IC displays various histological phenomena. While our TNF- $\alpha$ induced urothelial EMT and pro-fibrogenesis phenotype model is consistent with the clinical characteristics of BPS/IC, the cause of this phenomenon remains unclear, although it may be related to different activation of the Slug and Smad pathways.

Slug is a member of the Snail family of transcriptional factors, and is known to play an important role in the EMT and fibrogenesis $(23,31)$. The Smad pathway is associated with the EMT and fibrogenesis, and is mostly induced by TGF- $\beta(14,32)$. In this study, TNF- $\alpha$ activated Slug and Smad2 in urothelial cells and induced the EMT and profibrogenesis phenotype. It was interesting that, after $72 \mathrm{~h}$ of culture with different concentrations of TNF- $\alpha$, Slug was activated most obviously with $50 \mathrm{ng} / \mathrm{mL}$ TNF- $\alpha$, while Smad2 and phospho-Smad2 were activated most obviously at $10 \mathrm{ng} / \mathrm{mL}$. However, $2 \mathrm{ng} / \mathrm{mL} \mathrm{TNF-} \alpha$ was the only concentration to induce activation of the Smad2 pathway with statistical significance, suggesting that although TNF- $\alpha$ could stimulate Slug and Smad signaling, the concentration of TNF- $\alpha$ influenced the level of activity. Although the Slug and Smad pathways are both linked to the EMT and pro-fibrogenic phenotype, the Smad pathway may have a greater pro-fibrogenesis effect while the Slug pathway was more likely to induce the EMT in urothelial cells. Further research is warranted to confirm this hypothesis.

TGF- $\beta$ is the most famous cytokine in tissue fibrosis formation (18). However, in the present study, there was no obvious change in TGF- $\beta$ production. However, we cannot conclude that TGF- $\beta$ has no effect on the EMT and fibrogenesis in the TNF- $\alpha$-induced BPS/IC cell model. Co-activation exists between TNF- $\alpha$ and TGF- $\beta$ as TNF- $\alpha$ activates Smad signaling through TGF- $\beta$ receptor clustering (33). Smad2 plays an important role in TGF- $\beta$ induced Smad signaling (18). Our study showed Smad2 was activated in the TNF- $\alpha$-induced BPS/IC cell model, which could be due to co-activation between TNF- $\alpha$ and TGF- $\beta$ as Smad 2 was increased until the second $24 \mathrm{~h}$ of TNF- $\alpha$ culture. Evidence of co-activation of TNF- $\alpha$ and TGF- $\beta$ in BPS/IC is rare; more studies are needed to reveal the association of TNF- $\alpha$ and TGF- $\beta$ in the urothelium.

There were some limitations of our study. We assessed the effects of three concentrations of TNF- $\alpha$ in urothelial cells and determined $10 \mathrm{ng} / \mathrm{mL}$ to be an effective concentration. However, its underlying mechanism is still unclear. Vimentin and E-cadherin were assessed to evaluate EMT changes, and the production of three pro-fibrogenesis cytokines and collagen I was used to represent ECM deposition. Activation of Slug and Smad signaling, two classic EMT and fibrosis pathways, was used to assess the BPS/IC cell model. However, more comprehensive indexes should be considered in the future to investigate this model and to determine the underlying mechanism of fibrosis in BPS/IC.

\section{Acknowledgments}

Funding: This research was supported by the General Programs of the National Natural Science Foundation of China (No. 81970658), the General Programs of the Shanghai Science and Technology Commission (19ZR1432300) and the Youth Program of Shanghai Ruijin 
Hospital North (2020ZY06).

\section{Footnote}

Reporting Checklist: The authors have completed the MDAR reporting checklist. Available at https://dx.doi. org/10.21037/tau-21-392

Data Sharing Statement: Available at https://dx.doi. org/10.21037/tau-21-392

Conflicts of Interest: All authors have completed the ICMJE uniform disclosure form (available at https://dx.doi. org/10.21037/tau-21-392). The authors have no conflicts of interest to declare except the funding, of which the funders had no role in this study.

Ethical Statement: The authors are accountable for all aspects of the work in ensuring that questions related to the accuracy or integrity of any part of the work are appropriately investigated and resolved. The study was conducted in accordance with the Declaration of Helsinki (as revised in 2013). This research was approved by the Ethics Committee of Ruijin Hospital, Shanghai Jiao Tong University School of Medicine (No. 202134). Informed consent was obtained from all individual participants included in the study.

Open Access Statement: This is an Open Access article distributed in accordance with the Creative Commons Attribution-NonCommercial-NoDerivs 4.0 International License (CC BY-NC-ND 4.0), which permits the noncommercial replication and distribution of the article with the strict proviso that no changes or edits are made and the original work is properly cited (including links to both the formal publication through the relevant DOI and the license). See: https://creativecommons.org/licenses/by-nc-nd/4.0/.

\section{References}

1. van de Merwe JP, Nordling J, Bouchelouche P, et al. Diagnostic criteria, classification, and nomenclature for painful bladder syndrome/interstitial cystitis: an ESSIC proposal. Eur Urol 2008;53:60-7.

2. Colaco M, Evans R. Current guidelines in the management of interstitial cystitis. Transl Androl Urol 2015;4:677-83.

3. Colemeadow J, Sahai A, Malde S. Clinical Management of Bladder Pain Syndrome/Interstitial Cystitis: A Review on Current Recommendations and Emerging Treatment Options. Res Rep Urol 2020;12:331-43.

4. Pape J, Falconi G, De Mattos Lourenco TR, et al. Variations in bladder pain syndrome/interstitial cystitis (IC) definitions, pathogenesis, diagnostics and treatment: a systematic review and evaluation of national and international guidelines. Int Urogynecol J 2019;30:1795-805.

5. Grover S, Srivastava A, Lee R, et al. Role of inflammation in bladder function and interstitial cystitis. Ther Adv Urol 2011;3:19-33.

6. Kim A, Han JY, Ryu CM, et al. Histopathological characteristics of interstitial cystitis/bladder pain syndrome without Hunner lesion. Histopathology 2017;71:415-24.

7. Choi D, Han JY, Shin JH, et al. Downregulation of WNT11 is associated with bladder tissue fibrosis in patients with interstitial cystitis/bladder pain syndrome without Hunner lesion. Sci Rep 2018;8:9782.

8. Lv JW, Wen W, Jiang C, et al. Inhibition of microRNA-214 promotes epithelial-mesenchymal transition process and induces interstitial cystitis in postmenopausal women by upregulating Mfn2. Exp Mol Med 2017;49:e357.

9. Hanno PM, Erickson D, Moldwin R, et al. Diagnosis and treatment of interstitial cystitis/bladder pain syndrome: AUA guideline amendment. J Urol 2015;193:1545-53.

10. Jin XW, Liu BK, Zhang X, et al. Establishment of a Novel Autoimmune Experimental Model of Bladder Pain Syndrome/Interstitial Cystitis in C57BL/6 Mice. Inflammation 2017;40:861-70.

11. Suarez-Carmona M, Lesage J, Cataldo D, et al. EMT and inflammation: inseparable actors of cancer progression. Mol Oncol 2017;11:805-23.

12. Rosenbloom J, Macarak E, Piera-Velazquez S, et al. Human Fibrotic Diseases: Current Challenges in Fibrosis Research. Methods Mol Biol 2017;1627:1-23.

13. Fry CH, Kitney DG, Paniker J, et al. Fibrosis and the bladder, implications for function ICI-RS 2017. Neurourol Urodyn 2018;37:S7-S12.

14. Zhang Q, Chang X, Wang H, et al. TGF- $\beta 1$ mediated Smad signaling pathway and EMT in hepatic fibrosis induced by $\mathrm{Nano} \mathrm{NiO}$ in vivo and in vitro. Environ Toxicol 2020;35:419-29.

15. Gulluoglu S, Tuysuz EC, Sahin M, et al. The role of TNF- $\alpha$ in chordoma progression and inflammatory pathways. Cell Oncol (Dordr) 2019;42:663-77.

16. Wu ST, Sun GH, Hsu CY, et al. Tumor necrosis factor- $\alpha$ induces epithelial-mesenchymal transition of renal cell 
carcinoma cells via a nuclear factor kappa B-independent mechanism. Exp Biol Med (Maywood) 2011;236:1022-9.

17. Chuang MJ, Sun KH, Tang SJ, et al. Tumor-derived tumor necrosis factor-alpha promotes progression and epithelialmesenchymal transition in renal cell carcinoma cells. Cancer Sci 2008;99:905-13.

18. Meng XM, Nikolic-Paterson DJ, Lan HY. TGF- $\beta$ : the master regulator of fibrosis. Nat Rev Nephrol 2016;12:325-38.

19. Chen W, Yuan H, Cao W, et al. Blocking interleukin-6 trans-signaling protects against renal fibrosis by suppressing STAT3 activation. Theranostics 2019;9:3980-91.

20. Fielding CA, Jones GW, McLoughlin RM, et al. Interleukin-6 signaling drives fibrosis in unresolved inflammation. Immunity 2014;40:40-50.

21. Meier RPH, Meyer J, Montanari E, et al. Interleukin-1 Receptor Antagonist Modulates Liver Inflammation and Fibrosis in Mice in a Model-Dependent Manner. Int J Mol Sci 2019;20:1295.

22. Oh SY, Kim YH, Kang MK, et al. Aesculetin Attenuates Alveolar Injury and Fibrosis Induced by Close Contact of Alveolar Epithelial Cells with Blood-Derived Macrophages via IL-8 Signaling. Int J Mol Sci 2020;21:5518.

23. Fang CY, Hsia SM, Hsieh PL, et al. Slug mediates myofibroblastic differentiation to promote fibrogenesis in buccal mucosa. J Cell Physiol 2019;234:6721-30.

24. Liu JC, Wang F, Xie ML, et al. Osthole inhibits the expressions of collagen I and III through Smad signaling pathway after treatment with TGF- $\beta 1$ in mouse cardiac fibroblasts. Int J Cardiol 2017;228:388-93.

Cite this article as: Jin XW, Wang QZ, Zhao Y, Liu BK, Zhang X, Wang XJ, Lu GL, Pan JW, Shao Y. An experimental model of the epithelial to mesenchymal transition and profibrogenesis in urothelial cells related to bladder pain syndrome/ interstitial cystitis. Transl Androl Urol 2021;10(11):4120-4131. doi: 10.21037/tau-21-392
25. Parsons CL. The role of the urinary epithelium in the pathogenesis of interstitial cystitis/prostatitis/urethritis. Urology 2007;69:9-16.

26. Homma Y, Ueda T, Tomoe H, et al. Clinical guidelines for interstitial cystitis and hypersensitive bladder updated in 2015. Int J Urol 2016;23:542-9.

27. Feng YL, Chen DQ, Vaziri ND, et al. Small molecule inhibitors of epithelial-mesenchymal transition for the treatment of cancer and fibrosis. Med Res Rev 2020;40:54-78.

28. Mack M. Inflammation and fibrosis. Matrix Biol 2018;6869:106-21.

29. Jiang YH, Peng CH, Liu HT, et al. Increased proinflammatory cytokines, C-reactive protein and nerve growth factor expressions in serum of patients with interstitial cystitis/bladder pain syndrome. PLoS One 2013;8:e76779.

30. Whitmore KE, Fall M, Sengiku A, et al. Hunner lesion versus non-Hunner lesion interstitial cystitis/bladder pain syndrome. Int J Urol 2019;26 Suppl 1:26-34.

31. Ye X, Tam WL, Shibue T, et al. Distinct EMT programs control normal mammary stem cells and tumour-initiating cells. Nature 2015;525:256-60.

32. Derynck R, Zhang YE. Smad-dependent and Smadindependent pathways in TGF-beta family signalling. Nature 2003;425:577-84.

33. Takahashi E, Nagano O, Ishimoto T, et al. Tumor necrosis factor-alpha regulates transforming growth factorbeta-dependent epithelial-mesenchymal transition by promoting hyaluronan-CD44-moesin interaction. J Biol Chem 2010;285:4060-73. 